\title{
Minimasi Waste dan Lead Time pada Proses Produksi Leaf Spring dengan Pendekatan Lean Manufacturing
}

\author{
Riza Nur Madaniyah dan Moses Laksono Singgih \\ Departemen Teknik Industri, Fakultas Teknologi Industri, Institut Teknologi Sepuluh Nopember (ITS) \\ e-mail: moseslsinggih@ie.its.ac.id
}

\begin{abstract}
Abstrak-Perusahaan leaf spring (PLS) adalah perusahaan yang memproduksi leaf spring di Indonesia. Perusahaan ini mengalami beberapa permasalahan seperti terjadinya complaint customer dan internal defect. Dimana kedua permasalahan tersebut tidak sejalan dengan target perusahaan. Sehingga untuk dapat mencapai target yang diinginkan PLS amatan, maka diperlukan sebuah pendekatan untuk mengetahui berbagai aktivitas yang bernilai tambah, waste yang terjadi serta lead time proses produksi. Salah satunya dengan pendekatan lean manufacturing. Dengan strategi lean, perusahaan diharapkan mampu mengurangi terjadinya waste dan mengurang lead time proses produksi serta mampu meningkatkan rasio aktivitas yang bernilai tambah. Kondisi proses produksi leaf spring jenis multi leaf spring lokal pada perusahaan amatan akan digambarkan dalam value stream mapping. Waste yang terjadi akan diidentifikasi menggunakan metode waste assessment model, lalu dilakukan pemetaan secara detail menggunakan VALSAT dan analisis akar penyebabnya dengan root cause analysis (5 why), serta mengadopsi perhitungan RPN pada FMEA untuk mencari nilai RPN tertinggi dari akar penyebab hasil 5 Why. Pada kondisi awal, lead time yang dibutuhkan untuk menyelesaikan 100 unit multi leaf spring lokal adalah 901.64 menit, serta waiting 651.68 menit. Sedangkan pada kondisi setelah perbaikan adalah total lead time sebesar 824.97 menit dan waiting 416.66 menit. Sehingga dengan perbaikan yang diusulkan dapat menurunkan lead time $8.5 \%$ dan penurunan waiting $36.06 \%$.
\end{abstract}

Kata Kunci-Lean Manufatcuring, Risk Priority Number, Root Cause Analysis, Value Stream Mapping, Waste Assessment Model

\section{PENDAHULUAN}

L EAF SPRING atau pegas daun adalah komponen otomotif kendaraan yang digunakan sebagai penerima getaran atau goncangan roda agar getaran atau goncangan dari roda tidak menyalur ke rangka kendaraan. Leaf Spring digunakan oleh kendaraan berat, seperti truk, bus, sistem kereta api, dan lain-lain [1]. PLS amatan mengutamakan 3T, yakni tepat mutu, tepat waktu dan tepat biaya. Proses produksi yang akan diamati dalam penelitian ini adalah leaf spring jenis multi leaf spring lokal. Berikut ini merupakan gambar leaf spring lokal.

Dalam memproduksi leaf spring, PLS amatan mengalami beberapa permasalahan, seperti terjadinya complain customer, internal defect dan keterlambatan produksi yang melebihi target dari perusahaan. Permasalahan tersebut berdampak negatif bagi perusahaan, seperti menurunnya kepercayaan customer, menurunnya profit, meningkatkan lead time produksi, dll. Salah satu penyebab permasalahan tersebut adalah karena kerumitan proses dan banyaknya defect, serta adanya waiting dan inventory yang tidak terkontrol dan banyaknya produk yang repair. Dalam upaya untuk mencapai target perusahaan, salah satu pendekatan yang dilakukan adalah dengan menerapkan konsep lean manufacturing dengan melakukan identifikasi 7 waste yang terjadi pada proses produksi yang meliputi defect, waiting, excessive inventory, overproduction, excessive transportation, motion, dan inappropriate processing [2]. Upaya untuk melakukan efisiensi dapat dilakukan dengan menerapkan konsep lean manufacturing pada perusahaanv [3]. Dengan menerapkan konsep lean manufacturing pada industri otomotif dapat memberikan dampak positif seperti penurunan lead time, penurunan waiting time, serta mengurangi terjadinya defect [4].

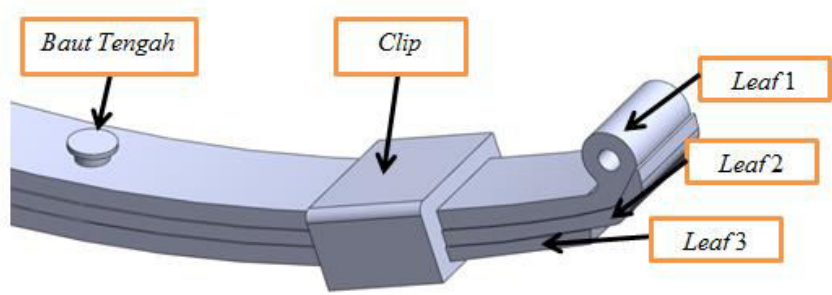

Gambar 1. Multi Leaf Spring Lokal.

Hal penting yang perlu diperhatikan pada proses produksi adalah bagaimana aliran proses produksinya, apa saja yang menjadi sumber pemborosan dan bagaimana cara menghilangkan atau meminimalkan pemborosan yang terjadi serta mempelajari hal-hal yang menunjang perbaikan dalam sistem produksi sehingga bisa memberi usulan perbaikan yang tepat.

\section{II.METODOLOGI PENELITIAN}

Observasi lapangan dilakukan secara langsung untuk mengamati kondisi nyata di perusahaan seperti proses produksi leaf spring, kondisi bahan baku, dan permasalahan yang sering dihadapi pada proses produksi leaf spring. Setelah dilakukan pengamatan maka dirumuskan beberapa masalah yang dianggap penting untuk dilakukan penelitian. Permasalahan tersebut adalah bagaimana meminimasi waste pada proses produksi leaf spring dengan pendekatan lean manufacturing.

Tahap pengumpulan dan pengolahan data dilakukan dengan cara wawancara, melihat langsung di lapangan dan penyebaran kuesioner. Secara jelas tahap ini dibagi menjadi beberapa langkah antara lain:

1. Identifikasi aliran proses produksi multi leaf spring lokal menggunakan value stream mapping. 
2. Identifikasi 7 waste dilakukan dengan penyebaran kuesioner untuk mendapatkan informasi dari pihak perusahaan mengenai waste apa saja yang terjadi di perusahaan dengan menggunakan metode waste assessment model. Terdapat 5 expert dalam perusahaan yang memahami proses produksi leaf spring sebagai responden, yakni manajer produksi, asisten manajer produksi, asisten manajer PPIC, asisten manajer QC, dan supervisor bagian produksi.

3. Identifikasi VALSAT, yakni dengan menggunakan bobot hasil waste assessment model sebagai input pembobotan VALSAT untuk memilih mapping tools yang tepat dalam mengidentifikasi penyebab terjadinya waste.

4. Identifikasi penyebab terjadinya waste kritis menggunakan metode 5 why's untuk mengetahui akar penyebab terjadinya waste kritis.

5. Penyebaran kuesioner FMEA untuk memperoleh nilai RPN tertinggi dari akar penyebab terjadinya waste. Expert dari kuesioner RPN FMEA adalah asisten manajer produksi, asisten manajer QC, asisten manajer PPIC, dan supervisor bagian produksi.

6. Perancangan usulan perbaikan pada proses produksi sesuai akar penyebab dengan nilai RPN paling tinggi.

7. Penarikan kesimpulan

\section{HASIL DAN PEMBAHASAN}

\section{A. Value Stream Mapping}

Value stream mapping adalah alat teknis untuk merancang sistem lean serta membuat gambar yang menekankan terjadinya waste, dengan adanya VSM dapat membantu melihat rantai terkait proses [5]. Dengan value stream mapping, dapat diketahui aliran informasi dan aliran material proses bisnis. Data yang diperoleh yang digunakan untuk value stream mapping adalah data sekunder yakni waktu standar setiap proses, jenis mesin, serta jumlah dan kapasitas mesin yang digunakan.

Berikut ini merupakan current state value stream mapping proses produksi multi leaf spring lokal perusahaan amatan dapat dilihat pada Gambar 2.

\section{B. Identifikasi Seven Waste dan VALSAT}

Identifikasi waste dilakukan menggunakan metode waste assessment model [6], dengan melakukan :

1. Metode seven waste relationship dan waste relationship matrix digunakan untuk mengetahui keterkaitan antara waste yang ada.

2. Metode waste assessment questionnaire untuk melakukan penilaian jenis pemborosan yang terjadi serta yang bersifat dominan.

Hasil identifikasi waste dengan menggunakan metode waste assessment model dapat dilihat pada Gambar 3.

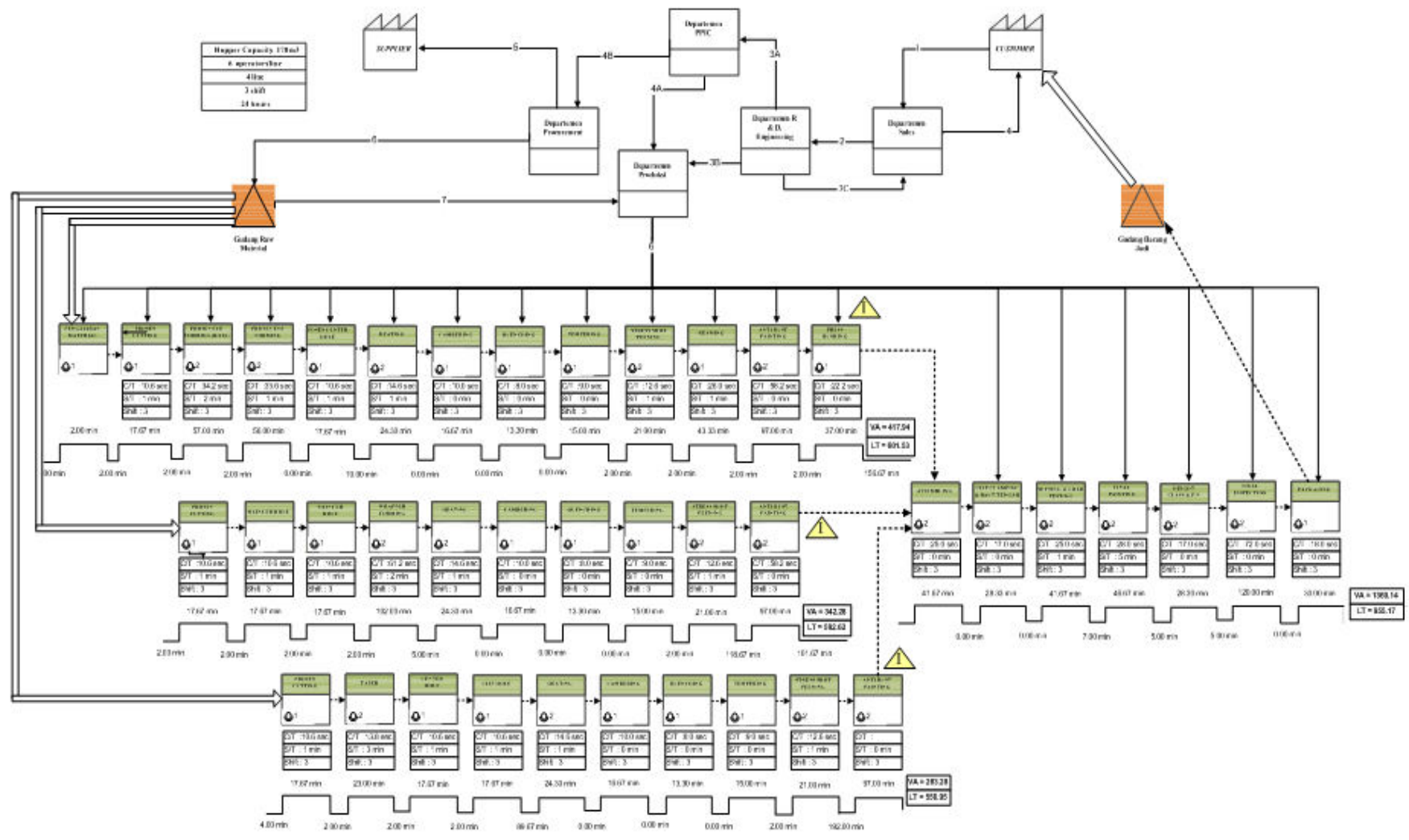

Gambar 2. Current State Value Stream Mapping. 


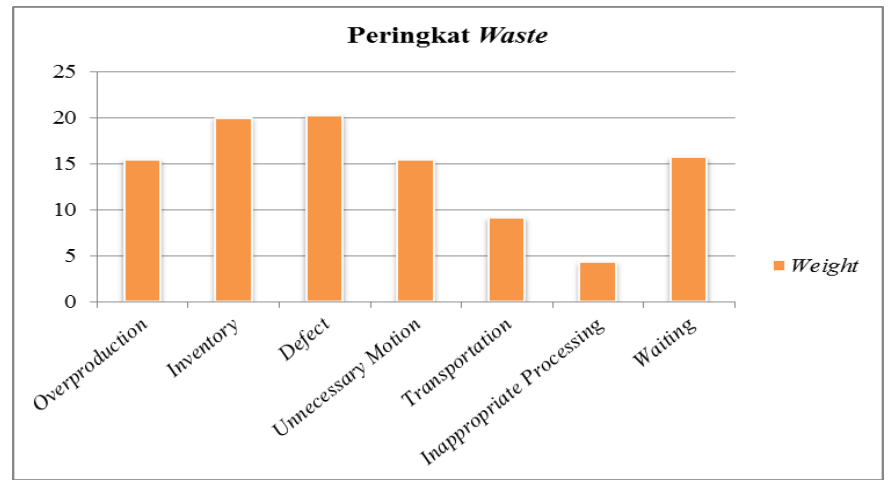

Gambar 3. Hasil Waste Assessment Model

Didapatkan jenis waste terbesar adalah defect (20.23\%), inventory $(19.93 \%)$ dan waiting $(15.65 \%)$. Setelah itu dilakukan pembobotan skor kuesioner untuk dikonversikan ke dalam matriks VALSAT untuk mendapatkan mapping tool yang dominan. Hasil dari konversi matriks VALSAT yang paling dominan adalah process activity mapping.

Process Activity Mapping merupakan tool yang digunakan untuk merekam seluruh aktivitas dari suatu proses dan berusaha untuk mengurangi aktivitas yang tidak bernilai tambah, sehingga dapat mengurangi waste yang terjadi [7]. Dalam tools ini, aktivitas diklasifikasikan ke dalam beberapa kategori, yakni operation, transport, inspection, dan storage. Berikut ini merupakan hasil akhir dari process activity mapping existing.

Tabel 1.

Hasil Akhir Process Activity Mapping

\begin{tabular}{|l|c|c|c|c|c|c|}
\hline \multicolumn{1}{|c|}{ Aktivitas } & Jumlah & Waktu & Prosentase & VA & NNVA & NVA \\
\hline Operation & 62 & 1297.76 & $48.8 \%$ & 36 & 24 & 2 \\
\hline Transportation & 25 & 119 & $4.4 \%$ & & 25 & \\
\hline Inspection & 3 & 122 & $4.6 \%$ & & 3 & \\
\hline Storage & 1 & & $0 \%$ & & 1 & \\
\hline Delay & 11 & 1117.71 & $42.2 \%$ & & 1 & 10 \\
\hline TOTAL & $\mathbf{1 0 2}$ & $\mathbf{2 6 5 6 . 4 7}$ & $\mathbf{1 . 0 0}$ & $\mathbf{3 6}$ & $\mathbf{5 4}$ & $\mathbf{1 2}$ \\
\hline
\end{tabular}

Tabel 2.

Akar penyebab dengan RPN tertinggi dan usulan perbaikan

\begin{tabular}{ccc}
\hline \hline Waste & Akar Penyebab & Usulan Perbaikan \\
\hline Defect & $\begin{array}{c}\text { Stopper yang digunakan } \\
\text { lentur dan mudah bengkok }\end{array}$ & $\begin{array}{c}\text { Pembuatan desain stopper } \\
\text { taper yang tidak lentur dan } \\
\text { tidak mudah bengkok } \\
\text { Pembuatan SOP } \\
\text { penanganan }\end{array}$ \\
Tidak adanya penggolongan & material tidak terpakai \\
& seperti scrap dan produk \\
defect & $\begin{array}{c}\text { material/produk waste dan } \\
\text { scrap serta penggolongan } \\
\text { jenisnya }\end{array}$ \\
Waiting & $\begin{array}{c}\text { Tidak adanya implementasi } \\
\text { 5S pada tools di lantai } \\
\text { produksi }\end{array}$ & $\begin{array}{c}\text { Pembuatan sistem 5S pada } \\
\text { tools }\end{array}$ \\
\hline \hline
\end{tabular}

\section{Analisis 5 Why dan FMEA}

Berdasarkan hasil waste assessment model, waste kritis yang dianalisis adalah waste defect, inventory dan waiting. Dilakukan identifikasi akar penyebab terjadinya waste kritis menggunakan 5 Why. Hasil identifikasi 5 Why akan digunakan sebagai input FMEA untuk mencari nilai RPN tertinggi dari akar penyebab terjadinya waste kritis.
Berikut ini merupakan hasil akhir akar penyebab dari masing-masing waste dengan hasil RPN tertinggi beserta usulan rekomendasi perbaikannya.

\section{Usulan Rekomendasi Perbaikan}

Berikut ini akan dijelaskan mengenai usulan perbaikan yang diusulkan sesuai dengan Tabel 2.

1. Pembuatan desain stopper taper yang tidak lentur dan tidak mudah bengkok.

2. Produk waste dan scrap serta penggolongan jenisnya.

Perusahaan leaf spring ini belum memiliki standar operasional prosedur (SOP) tertulis tentang penanganan terhadap material/produk defect dan scrap. Sehingga perlu dibuat SOP tertulis terhadap penanganan barang/produk defect dan scrap serta penggolongan jenis waste tersebut. Dalam pembuatan SOP ini, dilakukan wawancara dengan pihak perusahaan yakni dengan asisten manajer produksi dan asisten manajer QC. Wawancara dilakukan untuk memperoleh informasi terkait pengolahan material/produk defect dan scrap. Hasil wawancara tersebut kemudian dibuat sebagi referensi dalam pembuatan SOP, setelah SOP dibuat dilakukan validasi dengan asisten manajer produksi terkait isi dari SOP terhadap penanganan barang/produk defect dan scrap serta penggolongan jenis waste.

Tabel 3.

Kondsi Existing, Usulan Perbaikan Stopper Taper

\begin{tabular}{|c|c|}
\hline Kondisi Existing & Usulan Perbaikan \\
\hline $\begin{array}{l}\text { Stopper } 1 \text { pada mesin taper lentur dan } \\
\text { mudah bengkok karena material yang } \\
\text { digunakan tipis dan kekuatannya } \\
\text { lebih kecil dibandingkan dengan } \\
\text { material flat bar. } \\
\text { Stopper } 2 \text { material yang digunakan } \\
\text { sama dengan material flat bar, } \\
\text { dengan ketebalan dan kekuatannya } \\
\text { sama dengan flat bar. } \\
\text { Stopper } 1 \text { dan stopper } 2 \text { bukan } \\
\text { merupakan satu kesatuan komponen }\end{array}$ & $\begin{array}{l}\text { Stopper terbuat dari material yang } \\
\text { memiliki kekuatan minimal sama } \\
\text { dengan kekuatan material flat bar, } \\
\text { stopper } 1 \text { dan stopper } 2 \text { didesain } \\
\text { menjadi satu kesatuan, sehingga } \\
\text { material flat bar tidak dapat } \\
\text { terperosot kedalam stopper. } \\
\text { Stopper ini bersifat fleksibel (dapat } \\
\text { dipindahkan), sehingga dapat } \\
\text { menyesuaikan ukuran dari panjang } \\
\text { leaf spring yang akan dibentuk }\end{array}$ \\
\hline
\end{tabular}

leaf spring yang akan dibentuk

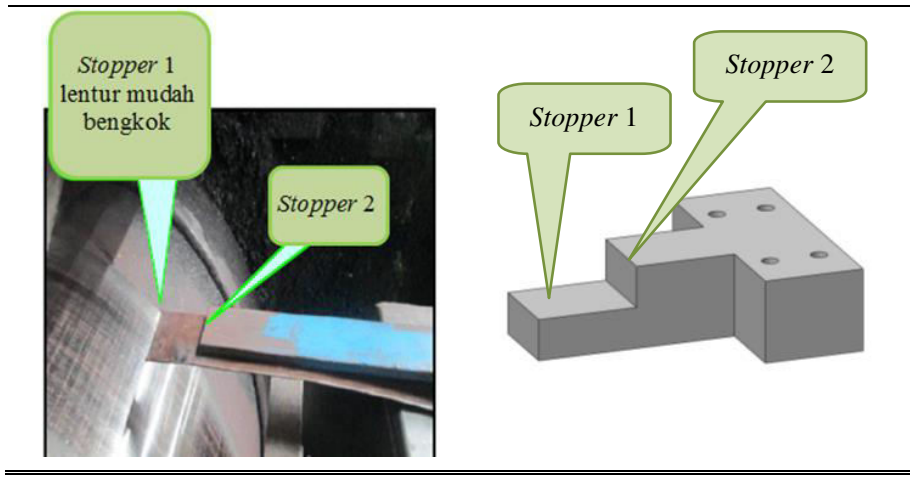

Pembuatan SOP penanganan material

Pembuatan sistem 5S pada tools 5S (Seiri, Seiton, Seiso, Seiketsu dan Shitsuke) atau yang lebih dikenal dengan 5R (Ringkas, Rapi, Resik, Rawat, dan Rajin), telah diterapkan oleh perusahaan spring amatan yang terbagi menjadi 2 aspek, 
yakni pada office dan shop floor. Namun dalam kenyataannya, 5S pada area shop floor tidak dilaksanakan dan tidak terkontrol dengan baik. Sehingga hal ini dapat menyebabkan terganggunya proses produksi perusahaan, seperti pencarian peralatan lebih lama, area lantai produksi tidak bersih, dan lain sebagainya.

Berikut ini beberapa temuan terkait $5 \mathrm{~S}$ pada tools di lantai produksi perusahaan amatan.

Tabel 4.

Temuan Kondisi 5S Perusahaan Amatan

\begin{tabular}{|c|c|c|}
\hline $\begin{array}{l}\text { Elemen } \\
5 \mathrm{~S}\end{array}$ & Temuan & Usulan Perbaikan \\
\hline Sort & $\begin{array}{l}\text { - Tools diletakkan secara } \\
\text { acak di rak } \\
\text { - Tidak terdapat } \\
\text { penggolongan jenis tools } \\
\text { Tools yang sudah tidak } \\
\text { dapat digunakan masih } \\
\text { terdapat di rak }\end{array}$ & $\begin{array}{l}\text { - Melakukan penataan tools } \\
\text { di rak, menggolongkan tools } \\
\text { berdasarkan jenis } \\
\text { - Menerapkan stratification } \\
\text { management berdasarkan } \\
\text { frekuensi penggunaan } \\
\text { - Menggunakan red tag pada } \\
\text { tools yang sudah tidak } \\
\text { digunakan lagi }\end{array}$ \\
\hline $\begin{array}{l}\text { Set in } \\
\text { order }\end{array}$ & $\begin{array}{l}\text { Tidak ada label / } \\
\text { identifikasi rak pada tools } \\
\text { komponen mesin }\end{array}$ & $\begin{array}{l}\text { Membuat label yang ditempel } \\
\text { pada rak untuk } \\
\text { mengidentifikasi jenis atau tipe } \\
\text { tools }\end{array}$ \\
\hline \multirow[t]{2}{*}{ Shine } & $\begin{array}{l}\text { Terdapat tools berserakan } \\
\text { di area produksi }\end{array}$ & $\begin{array}{l}\text { Meletakkan tools sesuai } \\
\text { dengan tempat yang telah } \\
\text { disediakan }\end{array}$ \\
\hline & $\begin{array}{l}\text { Almari peralatan kotor dan } \\
\text { berdebu }\end{array}$ & $\begin{array}{l}\text { Melakukan pembersihan lemari } \\
\text { secara berkala dari debu dan } \\
\text { kotoran }\end{array}$ \\
\hline \multirow[t]{2}{*}{$\begin{array}{c}\text { Standa- } \\
\text { rdize }\end{array}$} & $\begin{array}{l}\text { Tidak ada peraturan tertulis } \\
\text { untuk melakukan sorting, } \\
\text { set in order dan shine pada } \\
\text { tools. }\end{array}$ & $\begin{array}{l}\text { Membuat peraturan tertulis } \\
\text { untuk melakukan sorting, set in } \\
\text { order dan shine. }\end{array}$ \\
\hline & $\begin{array}{l}\text { Tidak adanya standar } \\
\text { dalam penyimpanan tools }\end{array}$ & $\begin{array}{l}\text { Membuat standar penyimpanan } \\
\text { tools }\end{array}$ \\
\hline Sustain & $\begin{array}{l}\text { Tidak adanya aturan } 5 \\
\text { minute for } 5 S \text { Tools diakhir } \\
\text { shift kerja }\end{array}$ & $\begin{array}{l}\text { Membuat aturan } 5 \text { minute for } \\
\text { 5S Tools di awal dan di akhir } \\
\text { shift kerja }\end{array}$ \\
\hline
\end{tabular}

Berdasarkan hasil temuan dan hasil pengamatan terhadap kondisi exsisting di atas, maka rancangan rekomendasi perbaikan sebagai berikut :

1. Sort
Rancangan usulan perbaikan Penerapan sort yang dapat diterapkan pada perusahaan spring ini adalah sebagai berikut :

- Menerapkan stratification management pada tools atau metode sorting yang lainnya

Tabel 5.

Usulan Stratification Management Tools

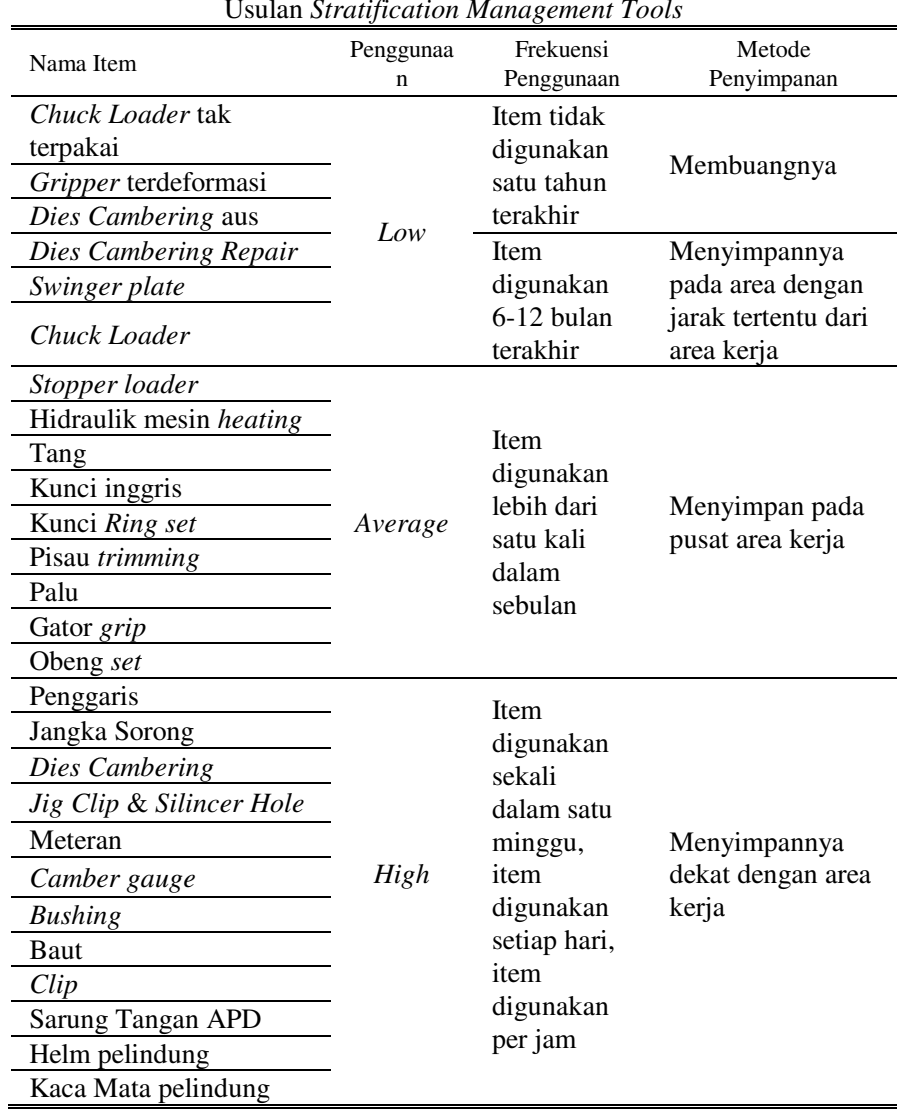

- Menerapkan sistem red tag

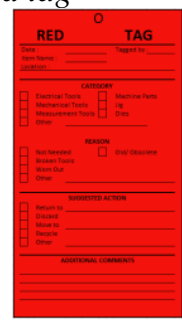

Gambar 4. Usulan Red Tag

Red tag digunakan sebagai identitas tool yang sudah tidak digunakan lagi untuk dilakukan pemusnahan, dijauhkan dari area kerja, serta pemindahan ke area karantina barang scrap/defect

- Menentukan area penyimpanan pada tools

- Membuat check list tools

2. Set in order

Penerapan set in order yang dapat diterapkan pada perusahaan spring ini adalah sebagai berikut :

- Memberikan label pada tools dan rak tools serta menentukan tempat dan lokasi penyimpanan tools

- Meletakkan tools yang sering digunakan lebih dekat, dapat menyusun tools dengan pemberian label seperti menggunakan shadow board jika memungkinkan. 


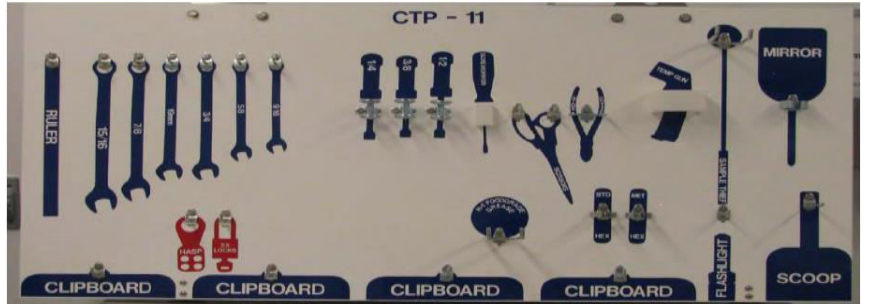

Gambar 5. Contoh shadow board [8]

- Meletakkan material dan peralatan pada tempat yang dialokasikan dengan label yang benar.

3. Shine

Penerapan shine yang dapat diterapkan pada perusahaan spring ini adalah sebagai berikut :

- Tidak menunggu sampai benda menjadi kotor. Bersihkan dan segera meletakkan tools yang telah selesai digunakan ke tempat atau rak yang disediakan.

- Kebersihan rak atau almari tools merupakan tanggung jawab seluruh karyawan

- Menjaga segala sesuatu dalam kondisi yang baik seperti memastikan bahwa tools tidak rusak, berada ditempat yang sesuai, serta almari atau rak tools dalam keadaan bersih

4. Standardize

Memberikan usulan perbaikan dengan membuat prosedur dokumen dan petunjuk untuk melakukan sorting, set in order, dan shine. Berikut ini merupakan peraturan untuk melakukan sorting, set in order, dan shine:

Peraturan sorting, set in order, shine pada tools :
1. Rapikan rak tools setelah selesai bekerja
2. Kembalikan semua tools setelah selesai digunakan kedalam rak
masing-masing sesuai jenis tools
3.Pastikan tools berada dirak yang telah ditentukan
4.Pastikan terdapat label pada tools dan pada rak tempat tools
5. Singkirkan semua tools yang sudah tidak terpakai
6.Pasangkan red tag pada tools yang sudah rusak atau atau sudah
tidak dapat digunakan
7.Bersihkan secara rutin area penyimpanan tools, rak tools, dan
tools $\quad$ ala kebersihan ada di area penyimpanan tools
8.Pastikan alat kap
b. Sulak
c. Kuas

\section{Sustain}

Diusulkan program 5 minutes $5 \mathrm{~S}$ for tools yang dilakukan diakhir pekerjaan. 5 minutes $5 S$ for tools merupakan program untuk melakukan pemeriksaan sederhana yang dilakukan di akhir pekerjaan untuk memastikan bahwa semua tools telah berada di lokasi atau rak yang sesuai, dengan jumlah yang sesuai, dan mengembalikan tools yang masih berada di area kerja. Selain itu memastikan bahwa almari atau rak tools bersih dari debu dan terdapat label pada masing-masing rak.

Prosedur 5 minutes $5 \mathrm{~S}$ for tools, diantaranya adalah :

- Membuat checklist tools harian pada Gambar 6,

- Mewajibkan setiap pekerja untuk melakukan dan memeriksa tools di area kerja masing-masing,

- Memastikan bahwa tidak terdapat tools yang berserakan di area kerja,

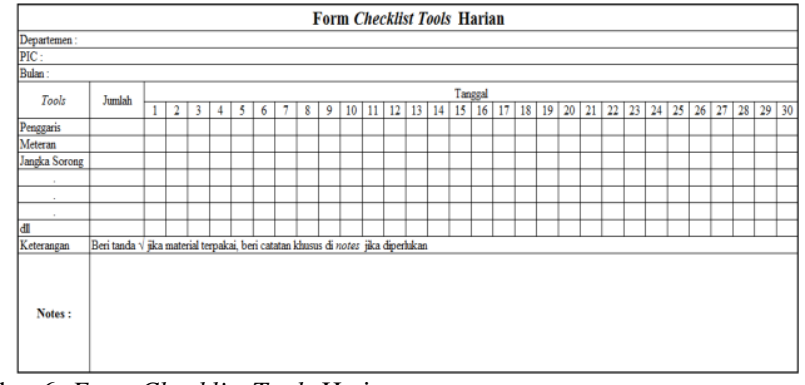

Gambar 6. Form Checklist Tools Harian

- Mewajibkan pekerja untuk memastikan bahwa rak atau area tools selalu bersih dan tidak berantakan,

- Pekerja pada masing-masing area mengisi check list tools harian.

\section{E. Future State Value Stream Mapping}

Future state value stream mapping merupakan konfigurasi value stream untuk transformasi lean yang diinginkan di masa yang akan datang setelah perbaikan telah dibuat. Perlu dibuat future state VSM karena terdapat beberapa aktivitas yang tidak bernilai tambah yang dapat dihapuskan. Selain itu dilakukan dilakukan standarisasi proses produksi dan perhitungan total waktu produksi dalam menyelesaikan 100 unit produk multi leaf spring lokal dengan tetap memperhatikan urutan proses produksi yakni proses seri dan paralel, jumlah mesin serta predesesor proses.

Terdapat 6 alternatif yang dapat digunakan, yakni :

Tabel 6.

Alternatif Proses Produksi Leaf Spring

\begin{tabular}{cc}
\hline \hline Alternatif & Total Lead Time (Menit) \\
\hline Leaf 123 & 901.64 \\
Leaf 132 & 901.64 \\
Leaf 213 & 834.97 \\
Leaf 231 & 901.64 \\
Leaf 312 & 841.34 \\
Leaf 321 & 824.97 \\
\hline \hline
\end{tabular}

Dari 6 alternatif, dipilih alternatif dengan lead time terpendek, yakni alternatif leaf 321 dengan total lead time 824.97. Berikut ini merupakan gambar future state VSM leaf 321 dapat dilihat pada Gambar 7.

Berdasarkan hasil future state VSM, maka berikut ini merupakan rasio perbandingan lead time dan waiting kondisi existing (current state VSM) dengan kondisi rekomendasi perbaikan (future state VSM).

Berdasarkan Tabel 7, dengan menerapkan future state VSM dapat menurunkan lead time dan waiting pada proses produksi multi leaf spring lokal. 
Tabel 7.

Perbandingan Current State dan Future State VSM

\begin{tabular}{cccc}
\hline \hline Parameter & $\begin{array}{c}\text { Exsisting } \\
\text { perusahaan } \\
\text { (menit) }\end{array}$ & $\begin{array}{c}\text { Rekomendasi } \\
\text { (menit) }\end{array}$ & $\begin{array}{c}\text { Selisih } \\
\text { (menit) }\end{array}$ \\
\hline
\end{tabular}

\begin{tabular}{lccc}
\hline $\begin{array}{l}\text { Total waktu proses } \\
\text { produksi }\end{array}$ & 901.64 & 824.97 & 76.67 \\
$\begin{array}{l}\text { Total delay/ } \\
\text { waiting }\end{array}$ & 651.68 & 416.66 & 235.02 \\
\hline \hline
\end{tabular}

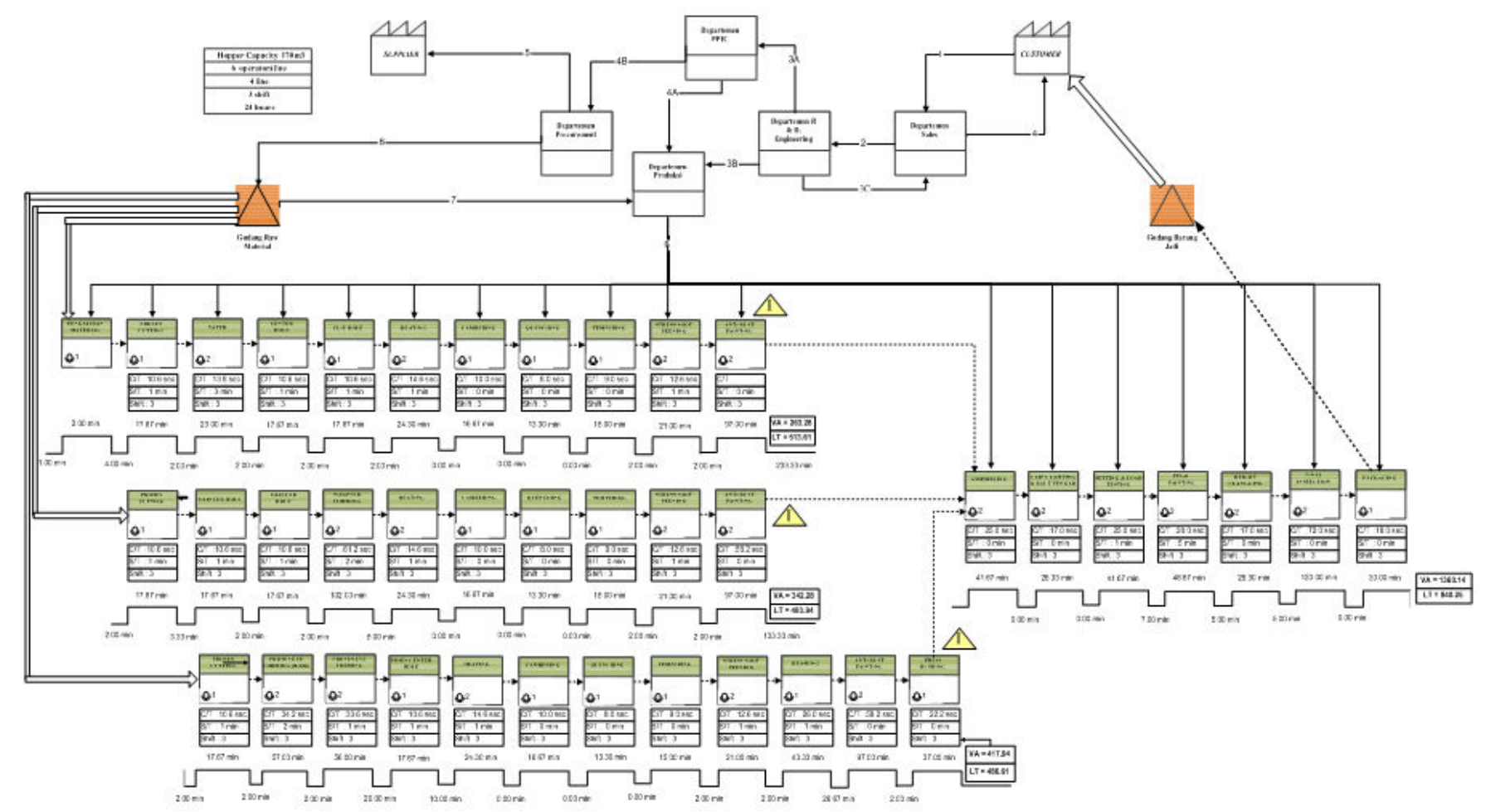

Gambar 7. Future State Value Stream Mapping.

\section{KESIMPULAN}

Kesimpulan yang didapatkan dari hasil pengolahan data dan analisis adalah sebagai berikut.

1. Berdasarkan hasil identifikasi waste dengan menggunakan metode waste assessment model, value stream mapping dan process activity mapping, dapat diketahui bahwa 3 waste kritis yang terjadi pada proses produksi leaf spring perusahaan amatan adalah defect, inventory dan waiting.

2. Akar permasalahan terjadinya waste defect diantaranya adalah material mudah bergeser yang dapat menyebabkan lubang clip yang dihasilkan bervariasi, stopper yang digunakan lentur dan mudah bengkok, gripper mengalami deformasi, sistem keluar masuk material dari gudang raw material belum ada dan tidak terdapat program terhadap pemantauan kinerja supplier. Sedangkan akar permasalahan terjadinya waste inventory adalah luas area gudang raw material tidak dapat menampung seluruh material yang dibeli, adanya perbedaan waktu selesai pada tiap tipe leaf, dan tidak adanya penggolongan material tidak terpakai seperti scrap dan produk defect. Dan akar permasalahan terjadinya waste waiting adalah banyak produk yang harus di repair, Tidak adanya implementasi 5S pada tools, Implementasi 5S tidak dijalankan sepenuhnya di gudang raw material.

3. Berdasarkan kondisi existing (current state VSM) proses produksi multi leaf spring lokal, waktu yang diperlukan untuk menyelesaikan 100 multi leaf spring lokal adalah 901.65 menit dengan total delay atau waiting 651.68 menit. Sedangkan berdasarkan usulan perbaikan (future state VSM), diperlukan waktu 824.97 menit dengan total delay atau waiting 416.66 menit. Sehingga dengan menerapkan future state value stream mapping terjadi penurunan lead

time sebesar 76.67 menit dan penurunan delay sebesar 235.02 menit.

4. Berdasarkan nilai RPN tertinggi, maka rekomendasi perbaikan untuk mengurangi akar permasalahan dari waste kritis adalah pembuatan jig pada mesin power press proses clip dan silincer hole, perbaikan desain stopper taper, pembuatan SOP penanganan material/produk defect dan scrap, dan penerapan $5 \mathrm{~S}$ pada tools di lantai produksi.

\section{DAFTAR PUSTAKA}

A. Saini and Dushyant, "Design and analysis of composite leaf spring for light vehicles," Int. J. Innov. Res. Sci. Eng. Technol., vol. 2, 2013.

[2] P. Hines and Taylor, "Going Lean, Lean Enterprise Research Center," United Kingdom, 2000.

[3] R. . Saputra and M. L. Singgih, "Perbaikan proses produksi blender menggunakan pendekatan lean manufactuirng di PT PMT," in Prosiding Seminar Nasional Manajemen Teknologi XV, 2012.

[4] M. T., "The Benefit Of Lean Manufacturing: What Lean Thinking Has To Offer The Process Industries," Trans IchemE Journals, vol. 83, no. 6, 2005.

[5] J. K. Liker and D. Meier, The Toyota Way. USA: Mc Graw Hill, 
2006.

I. Rawabdeh, "A model for the assessment of waste in job shop environments," Int. J. Oper. Prod. Manag., vol. 25, pp. 800-822, 2005.

[7] V. Ririyani and M. L. Singgih, "Peningkatan efisiensi di PT Varia
Usaha Beton dengan menerapkan lean manufacturing," in Prosiding Seminar Nasional Manajemen Teknologi XXIII, 2015. Accuform Sign, 5S Solution for the visual workplace. 2014. 